\title{
PENGARUH MEDIA BLOG (JURNAL ONLINE) TERHADAP KEMAMPUAN MENULIS PUISI SISWA KELAS X SMA NEGERI 1 RANTAU PRAPAT
}

\author{
Rosmawaty Harahap \\ Program Studi Pendidikan Bahasa dan Sastra Indonesia \\ Universitas Negeri Medan \\ Jalan Willem Iskandar Pasar V Medan Estate, Medan \\ Surel: rosmawatyharahap@gmail.com
}

\begin{abstract}
Abstrak
Penelitian ini bertujuan untuk mendiskripsikan adanya Pengaruh Media Blog (Jurnal Online) terhadap kemampuan menulis puisi siswa kelas X SMA N 1 Rantau Prapat Tahun Pelajaran 2017/2018. Populasi penelitian ini adalah seluruh siswa kelas X SMA Negeri 1 Rantau Parapat yang berjumlah 240 orang dan yang menjadi sampel pada penelitian ini sebanyak 40 orang yang diacak. Metode penelitian ini adalah metode eksperimen. Instrumen yang digunakan adalah tes dalam bentuk essai. Hasil analisis data menunjukkan bahwa ada perbedaan kemampuan menulis siswa tanpa menggunakan media blog (Jurnal Online) dan menggunakan media blog (Jurnal Online) pada siswa kelas X SMA Negeri 1 Rantau Parapat. Hal ini dapat dilihat dari perbedaan perolehan nilai rata-rata, yaitu menulis puisi dengan pengaruh media blog (jurnal online) dengan nilai rata-rata 74,12 sedangkan menulis puisi tanpa menggunakan media blog (jurnal online) dengan nilai rata-rata 65,12.
\end{abstract}

Kata Kunci : Media blog (Jurnal Online), menulis puisi

\section{A. PENDAhuluan}

Pengalaman sastra terwujud dari apa yang diketahui dan dirasakan oleh siswa yang berupa sensasi, emosi, dan gagasan-gagasan. Saat pengajaran berlangsung siswa harus diikutsertakan dalam pemecahan masalah sehingga siswa menjadi lebih aktif dan kreatif, sehingga siswa dapat mencapai kompetensi yang diharapkan. Kegiatan bersastra juga mengasah kemampuan siswa untuk memahami pikiran, perasaan, dan pendapat yang disampaikan oleh orang lain melalui bahasa. Salah satu tujuan pengajaran kesusastraan ialah menanamkan apresiasi sastra pada siswa. Dengan mengapresiasi sastra, siswa dapat secara langsung menikmati sebuah karya sastra, dari teori-teori tentang sastra sampai penerapan teori tersebut untuk memahami sebuah karya sastra.

Karya sastra merupakan hasik kreatif manusia yang dapat dimaknai dalam pembelajaran sastra khususnya menulis puisi merupakan sarana mengembankan daya piker atau nalar untuk mengkomunikasikan kegiatan ynang produktif dan ekspresif. Peran guru sebagai fasilitator sangat penting, guru hendaknya mampu mengajarkan 
pengetahuan tentang sastra terutama memahami puisi, kepada siswa sebagai salah satu dasar mereka dalam kegiatan menulis puisi. Pembelajaran menulis puisi juga akan dapat terlaksana dengan baik apabila ada kerjasama yang baik antara guru dan siswa. Guru sebagai fasilisator sangat penting memahami teknik-teknik dan penggunaan media, karena hal ini sangat berpengaruh dalam meningkatkan kemampuan menulis puisi. Pembelajaran yang dilakukan dalam menulis puisi masih tradisional seperti ceramah dan penugasan

Pembelajaran menulis puisi di SMA Negeri 1 Rantau Parapat masih belum maksimal terutama dalam penggunaan media pembelajaran. Hal ini berdasarkan berdasarkan observasi dan wawancara yang dilakukan dengan guru mata pelajaran bahasa Indonesia di sekolah tersebut. Oleh sebab itu, peneliti tertarik untuk melihat pengaruh penggunaan media blog (jurnal online) dalam proses pembelajaran menulis puisi di SMA Negeri 1 Rantau Parapat.

Tujuan penelitian ini adalah untuk mengetahui adanya pengaruh media blog (jurnal Online) terhadap kemampuan menulis puisi siswa kelas X SMA Negeri 1 Rantau Prapat. Lebih khusus lagi untuk mengetahui apakah melalui penggunaan media blog dapat meningkatkan kemampuan menulis puisi siswa kelas X SMA Negeri 1 Rantau Prapat tahun ajaran 2017-2018.

Penelitian ini juga diharapkan memberikan manfaat teoritis dan manfaat praktis. Manfaat teoritis adalah hasil penelitian ini diharapkan dapat memberi tambahan pengetahuan dalam teori pembelajaran bahasa, khususnya pembelajaran menulis puisi dengan menggunakan media blog ( Jurnal Online). Manfaat praktisnya adalah Bagi siswa, penelitian ini diharapkan dapat memotivasi siswa dalam meningkatkan kemampuan menulis puisi dan untuk membantu siswa dalam mengatasi kesulitan dalam pembelajaran menulis puisi. Bagi pihak sekolah, hasil penelitian ini dapat digunakan sebagai pengembangan proses pengajaran bahasa dan sastra Indonesia dalam meningkatkan kemampuan menulis puisi kelas X SMA Negeri 1 Rantau Prapat. Bagi guru, hasil penelitian ini dapat memberikan sumbangan pemikiran untuk menentukan pemilihan dan pemanfaatan media pembelajaran menulis puisi. 


\section{B. KAJIAN TEORI}

Pembelajaran merupakan proses, cara, perbuatan menjadikan orang atau mahluk hidup belajar. Pembelajaran merupakan upaya yang dilakukan dengan sengaja oleh pendidik untuk menyampaikan ilmu pengetahuan, mengorganisasi dan menciptakan sistem lingkungan dengan berbegai metode sehingga siswa dapat melakukan kegiatan belajar secara efektif dan efisien dan dengan hasil yang optimal. Dapat disimpulkan bahwa pembelajaran merupakan suatu proses penyampaian ilmu pengetahuan sehingga siswa dapat belajar secara efektif untuk mencapai hasil belajar yang optimal.

Media Blog ( Jurnal Online) salah satu jenis media berbasis internet. Blog adalah salah satu fasilitas yang terdapat di internet. Blog merupakan kependekan dari weblog. Blog adalah sebuah sarana menulis tempat semua orang bebas mengekspresikan apa yang ingin disampaikan. Tulisan tersebut dapat dilihat oleh semua pengguna internet. Sukiman (2012: 240) berpendapat "Blog atau weblog adalah teks dokumen, gambar, objek, media dan data yang tersusun secara hierarkhis dan menurut kronologi tertentu, yang dapat dilihat melalui browser internet”. Media Blog dapat dimanfaatkan dalam pembelajaran menulis puisi. Konsep pembelajaran menggunakan media Blog ini guru berusaha memadukan konsep mengajar konvensional yaitu keterlibatan guru di kelas dan konsep pengajaran berbasis internet.

Puisi merupakan salah satu karya seni bahasa yang mengungkapkan tema tertentu, sebelum berlatih menulis puisi, ada dua hal penting yang perlu diperhatikan. Waluyo (2018: 17) mengatakan bahwa "Tema adalah gagasan pokok yang dikemukakan oleh penyair melalui puisinya. Tema mengacu pada penyair, sedikit banyaknya pembaca harus mengetahui latar belakang penyair agar tidak salah menafsirkan tema puisi tersebut. Karena itu, tema bersifat khusus ( diacu dari penyair), objektif ( semua pembaca harus menafsirkan sama), dan lugas ( bukan makna kias yang diambil dari konotasinya)". Sugiarto (2013:23) berpendapat bahwa dalam menulis puisi, hal pertama yang harus dilakukan adalah menentukan tema. Tema adalah pokok pembicaraan yang mendasari sebuah puisi”.

Dalam puisi, kata-kata dapat memiliki dua makna, yaitu makna denotatif dan makna konotatif. Kata yang bermakna denotatif adalah kata yang mengandung makna yang sebenarnya atau dengan kata lain mengandung makna sebagaimana tertuang dalam kamus (tersurat). Adapun makna konotatif adalah makna tambahan yang timbul 
berdasarkan nilai rasa seseorang. Dalam bahasa puisi, bunyi $\mathrm{g}, \mathrm{j}, \mathrm{d}$ dan b melambangkan perasaan atau sesuatu yang berat. Bunyi i dan e melambangkan perasaan atau sesuatu yang ringan. Bunyi a, u,o menyatakan perasaan keruh, rendah, dan besar.

Penggunaan media Blog (Jurnal Online) diharapkan dapat dimanfaatkan untuk meningkatkan kemampuan menulis puisi siswa pada Sekolah Menengah Atas maka perlu dilakukan penelitian lebih lanjut.

\section{METODE PENELITIAN}

Penelitian ini dilaksanakan di SMA Negeri 1 Rantau Prapat Tahun Ajaran 2017/ 2018 pada semester ganjil, populasi dalam penelitian ini adalah seluruh siswa kelas X SMA Negeri 1 Rantau Prapat sebanyak 240 orang tersebar dalam 6 kelas paralel, cara yang dilakukan dalam penarikan sampel yaitu penarikan secara acak ( random sampling). Dalam hal ini yang dirandom bukan orangnya, melainkan kelasnya yaitu kelas X-1 sampai kelas X-6. Setelah dilakukan langkah-langkah tersebut, maka didapatlah kelas X-2 sebagai kelas eksperimen dengan sampel dalam penelitian ini berjumlah 40 siswa. Penelitian menggunakan metode eksperimen dengan model pretest dan post-test one group. Teknnis analisis data yang digunakan adalah teknik deskriptif, yaitu langkah yang pertama mendeskripsikan data, menghitung Uji Normalitas, Uji Homogenitas, dan Uji Hipotesis. Untuk menguji hipotesis ini dilakukan dengan cara membandingkan harga thitung dan $t_{\text {tabel }}$ dengan tingkat kepercayaan $\alpha=$ $0,05 \%$ dengan ketentuan jika $t_{\text {hitung }}>\mathrm{t}_{\text {tabel }}$, maka $\mathrm{H}_{0}$ ditolah dan $\mathrm{H}_{\mathrm{a}}$ diterima dengan pengertian ada pengaruh media blog (jurnal online) terhadap kemampuan menulis puisi siswa kelas X SMA Negeri 1 Rantau Prapat Tahun Ajaran 2017/ 2018.

\section{HASIL PENELITIAN DAN PEMBAHASAN}

Berikut ini akan dipaparkan hasil kemampuan siswa dalam menulis puisi siswa kelas X SMA Negeri 1 Rantau Parapat pada tahap pree-test dan post-test. Instrumen yang digunakan untuk menilai kemampuan siswa dalam menulis puisi adalah tes uraian dengan indikator penilaian sebagai berikut. Penilaian menulis puisi dilakukan dengan indikator kesesuaian isi dengan tema, diksi, dan gaya bahasa/majas. 
Tabel 1 Frekuensi Data Kemampuan Siswa Menulis Puisi tanpa Menggunakan Media Blog (Jurnal Online)

\begin{tabular}{c|l|c|c|c}
\hline \multirow{2}{*}{ No. } & \multicolumn{2}{|c|}{ Nilai } & Frekuensi & Presentasi \\
\cline { 2 - 3 } & \multicolumn{1}{|c|}{ Kategori } & Rentang Nilai & & \\
\hline 1. & Sangat Mampu & $90-100$ & 0 & - \\
\hline 2. & Mampu & $80-89$ & 15 & $37,5 \%$ \\
\hline 3. & Cukup & $70-79$ & 22 & $55 \%$ \\
\hline 4. & Kurang & $<70$ & 3 & $7,5 \%$ \\
\hline 5. & Sangat Kurang & $0-30$ & 0 & - \\
\hline & Jumlah & & 40 & $100 \%$ \\
\hline
\end{tabular}

Tabel di atas memperlihatkan bahwa kemampuan menulis puisi siswa tanpa menggunakan media blog (jurnal online) dengan kategori baik sebanyak 15 siswa atau $37,5 \%$, kategori cukup sebanyak 22 siswa atau 55\%, dan kategori kurang sebanyak 3 siswa atau 7,5\%. Rata-rata kemampuan siswa adalah dapat 65,12 dari jumlah siswa 40 orang. dengan standart deviasi 7,50 dan perolehan nilai tertinggi 80 dan terendah 50 .

Tabel 2 Frekuensi Data Kemampuan Siswa Menulis Puisi Menggunakan Media Blog (Jurnal Online)

\begin{tabular}{c|l|c|c|c}
\hline \multirow{2}{*}{ No. } & \multicolumn{2}{|c|}{ Nilai } & Frekuensi & Presentasi \\
\cline { 2 - 3 } & \multicolumn{1}{|c|}{ Kategori } & Rentang Nilai & & \\
\hline 1. & Sangat Mampu & $90-100$ & 6 & $15 \%$ \\
\hline 2. & Mampu & $80-89$ & 25 & $62,5 \%$ \\
\hline 3. & Cukup & $70-79$ & 9 & $22,5 \%$ \\
\hline 4. & Kurang & $<70$ & 0 & - \\
\hline 5. & Sangat Kurang & $0-30$ & 0 & - \\
\hline & Jumlah & & 40 & $100 \%$ \\
\hline
\end{tabular}

Dari data di atas terlihat bahwa kemampuan siswa menulis puisi dengan kategori sangat baik sebanyak 6 siswa atau 15\%, kategori baik sebanyak 25 orang atau $62,5 \%$, kategori cukup sebanyak 9 siswa atau 22,5\%. Rata-rata kemampuan siswa dengan menggunakan media blog ini adalah 74,12, standar deviasi berjumlah 7,82 dengan peroleh nilai tertinggi 90 dan terendah 60 . 
Dari hasil penelitian terlihat bahwa kemampuan siswa dalam menulis puisi kelas X SMA Negeri 1 Rantau Parapat Tahun Ajaran 207/2018 dengan menggunakan media blog (jurnal online) lebih efektif dibandingkan tanpa menggunakan media blog. Hal ini terlihat dari nilai rata-rata siswa secara keseluruhan dengan menggunakan media blog lebih tinggi dibandingkan tanpa menggunakan media blog.

Berdasarkan aspek penilaian pada menulis puisi, skor siswa yang paling rendah baik menggunakan media blog dan tanpa menggunakan media blog pada bagian diksi dan gaya bahasa/majas. Untuk bagian tema, secara keseluruhan siswa sudah dapat menyesuaikan tema denga isi puisi keseluruhan.

Perhitungan interpolasi diketahui bahwa $t_{\text {hitung }}=5,20$. Maka dengan mengkonsultasikan hasil tersebut dengan $\mathrm{t}_{\text {tabel }}$ pada taraf signifikan $5 \%$ dan $1 \%$ dan derajat kebebasan $n_{1}+n_{2}-2=78$ maka diketahui nilai $t_{\text {tabel }}$ adalah untuk taraf signifikan $5 \%=1,99$ dan $1 \%=2,64$. Dengan demikian diketahui bahwa $t_{\text {hitung }}>t_{\text {tabel }}$ yaitu $(5,20>$ 1,99) pada taraf signifikan $5 \%$ dan $(5,20>2,64)$ pada taraf signifikan $1 \%$ maka dapat diambil kesimpulan bahwa pengaruh media Blog ( Jurnal Online) berpengaruh signifikan terhadap peningkatan kemampuan menulis puisi siswa kelas X SMA Negeri 1 Rantau Prapat Tahun Pembelajaran 2017/2018. Hal ini juga berarti bahwa hipotesis penelitian ini diterima.

\section{E. SIMPULAN}

Berdasarkan hasil penelitian kemampuan menulis puisi tanpa media blog (jurnal online) diperoleh nilai rata-rata berjumlah 65,12, dengan standart deviasi 7,50 dengan perolehan nilai tertinggi 80 dan terendah 50. Hasil penelitian kemampuan menulis puisi dengan pengaruh media blog (jurnal online) diperoleh nilai rata-rata 74,12, dengan standart deviasi berjumlah 7,82 dengan peroleh nilai tertinggi 90 dan terendah 60 . Kemampuan menulis puisi dengan pengaruh media blog (jurnal online) lebih efektif daripada menulis puisi tanpa media blog (jurnal online). Hal ini dapat dilihat dari perbedaan perolehan nilai rata-rata, yaitu menulis puisi dengan pengaruh media blog (jurnal online) dengan nilai rata-rata 74,12 sedangkan menulis puisi tanpa menggunakan media blog (jurnal online) dengan nilai rata-rata 65,12. Hal ini juga dapat 
dibuktikan dengan pengujian hipotesis, yakni $t_{0}$ yang diperoleh lebih besar dari $t_{\text {tabel }}$ yaitu, $1,99<5,20>2,64$. Karena $t_{0}$ yang diperoleh lebih besar dari $t_{\text {tabel }}$, maka dapat dinyatakan $\mathrm{H}_{0}$ ditolak dan $\mathrm{H}_{\mathrm{a}}$ diterima. Hal ini membuktikan bahwa pembelajaran menulis puisi dengan pengaruh media blog (jurnal online) lebih efektif.

\section{F. SARAN}

Pada penelitian selanjutnya diharapkan dapat dilakukan penelitian dengan menggunakan media yang lebih interaktif dan menyenangkan siswa dalam proses pembelajaran menulis puisi. Selain penggunaan media, hal yang perlu diperhatikan adalah pemilihan metode dan model pembelajaran dalam menulis puisi.

\section{DAFTAR PUSTAKA}

Arikunto, Suharsimi. 2019. Prosedur Penelitian : Suatu Pendekatan Praktik. Jakarta : Rineka Cipta.

Kusumah, Wijaya. 2012. TIK: Menulis Blog Untuk Pendidikan. Jakarta. Munsy, Alif Danya. 2012. Jadi Penulis? Siapa Takut!. Bandung: KAIFA. Mursini, 2010. Bimbingan Apresiasi Sastra Anak-Anak. Medan: USU Press.

Rudi Susilana dan Cepi Riana. 2009. Media Pembelajaran. Bandung: CV. Wacana Prima.

Sayuti, Suminto A. 2019. Berkenalan dengan Puisi. Yogyakarta: Gama Media. Sudjana, 2018. Metoda Statistika. Bandung: Tarsito.

Sugiarto, Eko. 2013. Cara Mudah Menulis Pantun, Puisi, Cerpen. Yogyakarta: Sugiono. 2019. Metode Penelitian Pendidikan. Bandung: Alfabeta.

Sukiman. 2012. Pengantar Media Pembelajaran. Yogyakarta: Pedagogia. Waluyo, Herman J. 2018. Apresiasi Puisi. Jakarta: PT Gramedia Pustaka Utama. Wena, Made. 2010. Strategi Pembelajaran Inovatif Kontemporer. Jakarta: Bumi Aksara. 